The Council for the Irish Centre

STATEMENT OF ACCOUNTS for the YEAR BNDED

31st DECEMBER 1965

Balance Sheet as at 31st December 1965

$\frac{\text { Year } 1964}{£}$

Assets

Fixed Assets

Freehold Premises \& Bullding Extensions

46,572

-

1,203

88

510

$\frac{-}{48,373}$

139

$\frac{2,469}{50,981}$
Camden Square \& North Villas

Hornsey Lane Gardens

Furmiture \& Fittings

Soft Furnishings

Catering \& Kitchen Equipment

Motor Vehicle

Current Assets

Sundry Debtors \& Prepayments

Stocks on Hand

$59,778 \quad 1,783$

57,995

$6,500-$

$5,729 \quad 3,506$

6,500

$1,256 \quad 1,001$

2,223

$2,054 \quad 1,384$

255

$\frac{685}{76,002} \quad \underline{137}$

187

$2,734-\frac{2,921}{71,112}$

Deduct Iiabilities

Ioans

Archdiocese of Westminster

Total advanced

15,000

Less Repaid: To 31 December

$$
1964 \cdot 6,500
$$

Year to date 1,500

8,500

Irish Clergy

Banks

$$
\begin{aligned}
& -\frac{7,000}{1,530} \\
& 1,530 \quad 8,530 \\
& \frac{\text { Nat- }}{\text { ional }} \frac{\text { West- }}{\text { Bank }} \quad \underline{\frac{\text { sin- }}{\text { Bank }}}
\end{aligned}
$$

(Secured by Guarantees of a Third Party and Deposit of Deeds of Freehold Property)

Loans

$30,522 \quad 2,000$

Less Balances at Bank

11,757

$$
\frac{5,653}{24,869} \quad \frac{1,245}{755} 25,624
$$

4,387 
$\frac{\text { Year } 1964}{£}$

Funds

\section{Welfare Fund}

$$
\text { Balance as at 3lst December } 1964
$$

Iess Transferred to General Fund

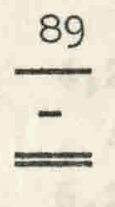

General Fund

Add In respect of The Girls' Hostel Hornsey Iane Gardens assumed during the year by the Trustees for the Irish Centre

Add Received during the year: Covenants

Appeals, Collections and Donations

Deduct

Excess of Expenditure over Income as per attached accounts:-

The Irish Centre

The Girls' Hostel

The Irish Centre Club

\section{DONNELIY}

REV . O.R. SWEENEY

\section{CHAIRIIAN}

HON. TREASURER

\section{Report of the Auditors to The Council for the Irish Centre}

We have examined the annexed Balance Sheet dated the 31st December 1965 and the attached Income \& Expenditure Accounts for the year ended that date with the books and records of the Irish Centre, the Irish Centre Club and the Girls' Hostel and have obtained such information and explanations as we have required. We certify that such Balance Sheet and Income and Expenditure Accounts are correct in accordance with the books and information and explanations given to us.

Orient House, 42-45, New Broad street, Iondon, E.C.2. 
The Council for the Irish Centre

The Irish Centre, Camden Square, Iondon, N.W.I.

Income and Expenditure Account for the vear ended 31st December, 1965

$\frac{\text { Year } \quad 1964}{£}$

4,310

275

3,800

-

332

1,259

169

1,971

632

320

79

970

-
Expenditure

Food

Laundry

Staff Salaries

Superannuation Fund

Rates

Iighting \& Heating

Insurance

Repairs and Naintenance

Telephone, Postage \& Stationery

General Expenses, Cleaning etc.

Year ended 31st December

$£$

$\underline{1965}$

$£$

Audit Fee

Ioan Interest \& Bank Charges

Welfare Expenditure

4,229

498

6,281

96

369

1,262

197

2,149

1,161

221

53

1,934

2,029

Depreciation and Amounts written off:-

401

Furniture \& Fittings

804

Catering \& Kitchen Equipment

335

Soft Furnishings

Notor Vehicle

81

$137 \quad \frac{1,357}{21,836}$

14,817

3,211

11,606

7,162

626

4258,213

Deduct Income

Deduct Charge to Irish Centre

club for rental and maintenance for the year 1965

5,912

15,924

Contributions to Board and

4,772 Iodging

Rent Receivable

Net Surplus on Functions

109

924

Balance being Excess of Expenditure over Income for the Year carried 
The Council for the Irish Centre

The Girls' Hostel, Hornsey Lane Gardens, London, N.19.

Income and Expenditure Account for the

Year ended 31st December, 1965

$\frac{\text { Year } 1964}{£}$

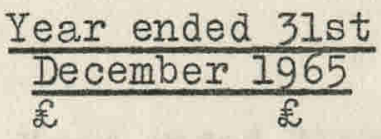

Expenditure

1,752

Food

1,937

Iaundry

119

933

Staff Salaries

1,147

172

Rates

120

445

Iighting \& Heating

473

Insurance

33

Repairs \& Naintenance

684

Telephone, Postage \&

Stationery

General Expenses

Ioan Interest \& Repayment

Welfare Expenditure

Deduct Income

4,054

Contributions to Board and Iodging

Balance being Excess of Expenditure over Income for the Year carried 


\section{The Council for the Irish Centre}

\section{The Irish Centre Club, Camden Square, London, N.W.I.}

Income and Expenditure Account for the

Year ended 3lst December, 1965

$\frac{\text { Year } 1964}{£}$

$\frac{\text { Year ended 31st }}{\frac{\text { December 1965 }}{£}}$

Expenditure

2,618 Wages

3,005

56 Stocktakers' Charges

59

3,211

Rental \& Maintenance Charges

5,912 for the Year

5,885

Deduct Income

4932 Surplus on Sales to Members

5,522

629 Net Surplus on Entertainments

1,391

194 Subscriptions

135

5,755

7,048

Balance being Excess of Expenditure

$£ 130$ over Income for the Year carried to Balance sheet 